\title{
Evaluation of the Effect of Sociocultural Factors on the Children Stature in Langkat Regency, Indonesia
}

\author{
Siti Saidah Nasution*(D), Bina Melvia Girsang (D), Hariati Hariati (D) \\ Department of Maternity and Pediatric Nursing, Faculty of Nursing, Universitas Sumatera Utara, Medan, Indonesia
}

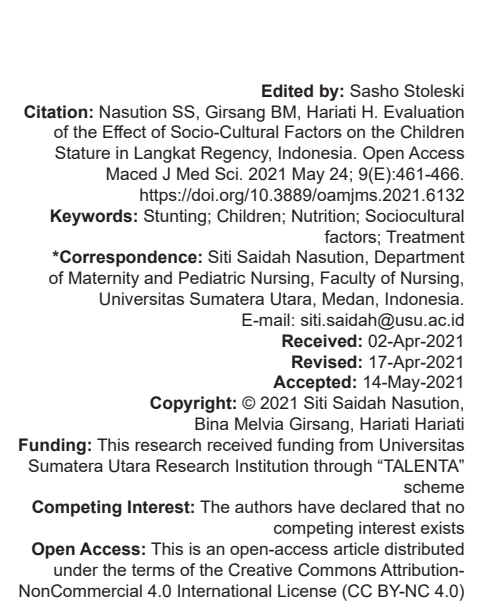

Introduction

The growth and development started from infancy level is an important issue and is a concern of the government. Adequacy and fulfillment of nutritional needs are compulsory to achieve an optimum growth and development for physical, psychomotor, psychological, mental, and social development. The higher the risk factors for malnutrition, the greater the chance that nutritional disorders will occur [1], [2]. One result of nutritional disorders that are currently developing is stunting. Stunting illustrates chronic nutritional status during the child's growth and development since early life [3], [4]. Indonesia is one of the 117 countries in the world that has high nutritional problems in infants; namely, stunting, wasting, and overweight, reported in the 2014 Global Nutrition Country Nutrition Report Indonesia Profile [5]. In particular, stunting is the biggest problem, with an incidence of up to $37.2 \%$ [6], [7]. One area with a high incidence of stunting in North Sumatra is Langkat district with a stunting prevalence reaching of $55.48 \%$.

Stunting (short stature) is an indication of a lack of nutritional intake, both in quantity and quality since the infant period, even in the womb [8], [9], [10]. This condition causes the child to have a body height that tends to be short in his age 8 . In addition to being short, stunting also has other effects on toddlers, both short-term and longterm impacts. Short-term effects can relate to the hamper of development, cognitive decline in immune function, and easier to be affected by the disease compared to other children in general [11], [12]. On the other hand, longterm effects can take up to adulthood, such as increasing the risk of degenerative diseases such as diabetes mellitus, coronary heart disease, hypertension, and obesity [13], [14]. Determining stunting in children was done by means of measurement. Height measurements by age were performed on children over 2 years old. Moreover, anthropometry is a measure of the body, whereas nutritional anthropometry is a type of measurement of some body shapes and body composition according to age and nutritional level, which is used to determine protein and energy imbalances. In addition, anthropometry is used to measure height and weight growth to assess nutritional adequacy [15], [16], [17], [18].

One factor that influences health status, including the fulfillment of family nutrition, is the culture of society [19]. Culture is a characteristic that 
will influence behavior and habits. Moreover, cultural values are concepts about something that is in the mind of most of the people who are considered valuable, and important in life, so that it can function as a guide that gives direction and orientation to the lives of the citizens [20], [21], [22], [23], [24], [25]. Cases of illness and infant death due to cultural perceptions that do not support the achievement of good conditions are still commonly found in various places in Indonesia, including in communities in the Secanggang subdistrict, Langkat Regency, North Sumatra, Indonesia. Socioculture is a scientific effort to understand cultural events/ statements which are generally unique and carried out as a tradition in people's lives. The socioculture of the community needs to be studied and analyzed to help the understanding and perception of the community in meeting their health-related needs [26], [27].

Basic sociocultural importance is to foster and questioning people's sensitivity to cultural values, to broaden views on humanitarian and cultural issues, and to develop an understanding of criticism about the ways humans express their experiences in the world in works of art [28], [29]. Social and cultural aspects greatly affect the life patterns of humanity, including health care for infants and children. The health status of a child is determined by the family through care taken in meeting food needs [30], [31]. Furthermore, children with poor health status, poor nutrition, and stunting associated with care are carried out starting from pregnancy and childbirth [19], [32]. Early and exclusive breastfeeding is the beginning of fulfilling good nutrition for babies. The willingness of mother and family to meet the nutritional adequacy of children is a major factor to prevent stunting [19], [32]. In the era of globalization with various changes that are so extreme recently, it requires a great attention of community to the sociocultural aspects. Therefore, maternal and child health is categorized as a focus of government achievement in the health sector [33].

The high number of morbidity and mortality rate for mothers and children is inseparable from social, cultural, and environmental factors in the surrounding community [19], [32], [33], [34]. Cases of illness and infant mortality as well as achievements in nutritional status are indicators to determine success in assessing the health status of infants and children in an area in Indonesia. Intervention performed by government to deal with stunting was to launch a national action plan program for handling stunting in August 2017, with an emphasis on convergence activities at the national, regional, and village levels to prioritize intervention activities for specific and sensitive nutrition in the first 1000 days of life to age of 6 years old. Government programs will run smoothly if carried out by involving the community, so it is necessary to do a preliminary assessment and how everyday social culture is associated with stunting.

Factors that affect health in terms of sociocultural aspects are varied. First, socioeconomic includes employment, income, and housing conditions. Low socioeconomic conditions are more likely to lead to rapid disease transmission, poor nutrition, and dense housing. Second, low education and knowledge affect the level of awareness of health and prevention of disease [31]. Women with high levels of education tend to focus more on the health of their families. Unhealthy living behaviors such as defecation in open channels or soil, eating without washing hands, bathing at times, alcoholics, and smokers can affect health status [35], [36]. Furthermore, bad environmental irritation, a dense and slum environment, and a house without good ventilation will affect the growth and development of children [37], [38], [39]. In addition, cultural behavioral factors including traditions that exist in society such as cultural views regarding pregnancy, birth, illness, and death in each region differ according to the beliefs and customs that are adhered could lead to the community health status.

\section{Methods}

This is a quantitative study with a descriptive correlation design, using questionnaire consisting of demographic data, infant/child health status, and sociocultural community as the research instrument. The socioculture of the community is seen from the family aspect by examining the socioeconomic, education, and attitude toward health and environmental sanitation.

The population in this study were all babies and toddlers in the Langkat district, especially the working area of the Secanggang Public Health Center, Secanggang district. As many as, 136 babies and toddlers were categorized as samples using total sampling method.

The baby's health status related to stunting was checked with measuring their height by age. Stunting describes a chronic undernutrition status during a child's growth and development since early life. This situation is presented with a height score for age (height/age) <2 standard deviation based on growth [16]. Stunting (short stature) is an indication of a lack of nutritional intake, both in quantity and in a quality that are not fulfilled since infancy, even in the womb. This condition causes children to have a short stature at their age.

The statistical method used was a univariate and bivariate analysis using the Chi-square statistical test, with significant indicator determination $(p<0.05)$. Moreover, multivariate analysis was carried out through logistic regression tests to measure the factors that most influence the incidence of stunting. 


\section{Results}

In general, results of the study found a social cultural relationship between the community and the stunting incident. Associated sociocultural factors are categorized to be environmental sanitation, parents educational background, family income, and mother's knowledge of stunting. In detail, all statistical results obtained were described in tables.

The sociocultural level is determined by examining several things according to predetermined indicators (Table 1), including socioeconomy, education, and attitude toward health and environmental sanitation. Socioculture that affects stunting includes environmental sanitation, father's and mother's education, family income, and maternal knowledge about stunting. The program to improve community health status will not run smoothly as intended if it does not assess environmental and cultural factors of the surrounding community and involve the community in the program [12], [19].

\section{Discussion}

The research results are consistent with the concept that explains that factors which cause stunting are poor parenting practices (Table 2), including lack of maternal knowledge about health and nutrition before, during, and after pregnancy [40], [41]. Some facts and information show that $60 \%$ of children aged 0-6 months do not get exclusive breast milk, even though breast milk is the perfect food source for babies. Moreover, it can shape endurance and the development of the immunological system. The people, especially mothers, in general say that children older than 1 year are not given various complementary foods, with the reason that the child does not want to eat. Therefore, family or mothers should start introducing additional food when toddlers are over 6 months old. Besides functioning to introduce new types of food to babies, it can also meet the nutritional needs of the baby's body that is not obtained by breast milk. The role and knowledge of the mother about breastfeeding are very crucial in fulfilling the nutrition of babies in accordance with their needs. The success of a nursing mother is determined by the success of the $1^{\text {st }}$ time to decide on giving breastfeed from birth [32].

At present, health services including antenatal care services (health services for mothers during pregnancy), postnatal care, and early quality learning are still limited. This condition affects family knowledge about health and the lack of information received related to the fulfillment of nutrition and stunting problems in children [42], [43], [44]. In fact, almost $25 \%$ of children/ babies are having stunting condition (Table 3 ). The
Table 1: Descriptive statistics of characteristics and socioculture of respondents $(n=136)$

\begin{tabular}{|c|c|c|}
\hline \multirow[t]{2}{*}{$\begin{array}{l}\text { Variable } \\
\end{array}$} & \multicolumn{2}{|l|}{ Frequency } \\
\hline & Numbers & Percentage \\
\hline \multicolumn{3}{|l|}{ Mother's age } \\
\hline $\begin{array}{l}\text { At risk }<20 \text { years old and }>35 \\
\text { years old }\end{array}$ & 52 & 38.2 \\
\hline Not at risk/20-35 years old & 12 & 32.43 \\
\hline \multicolumn{3}{|l|}{ Number of children } \\
\hline Primigravida & 26 & 19.1 \\
\hline $1-2$ & 74 & 54.4 \\
\hline$>2$ & 36 & 26.5 \\
\hline \multicolumn{3}{|l|}{ Father's educational background } \\
\hline Elementary & 13 & 9.6 \\
\hline Junior high school & 40 & 29.4 \\
\hline Senior high school & 65 & 47.8 \\
\hline Higher education & 18 & 13.2 \\
\hline \multicolumn{3}{|l|}{ Mother's educational background } \\
\hline Elementary & 37 & 27.2 \\
\hline Junior high school & 48 & 35.3 \\
\hline Senior high school & 41 & 30.1 \\
\hline Higher education & 10 & 7.4 \\
\hline \multicolumn{3}{|l|}{ Father's occupation } \\
\hline Entrepreneur & 39 & 28.7 \\
\hline Civil servant & 31 & 22.8 \\
\hline Farmer & 48 & 35.3 \\
\hline Fisherman & 18 & 13.2 \\
\hline \multicolumn{3}{|l|}{ Mother's occupation } \\
\hline Housewives & 68 & 50 \\
\hline Entrepreneur & 30 & 22.1 \\
\hline Civil servant & 26 & 19.1 \\
\hline Farmer & 11 & 8.1 \\
\hline Fisherman & 1 & 0.7 \\
\hline \multicolumn{3}{|l|}{ Income } \\
\hline Rp. $3,400,000$ & 100 & 73.5 \\
\hline$<$ Rp. $3,400,000$ & 36 & 26.5 \\
\hline \multicolumn{3}{|l|}{ Religion } \\
\hline Islam & 112 & 82.4 \\
\hline Christian & 24 & 17.6 \\
\hline
\end{tabular}

availability of health services in the community can help in improving the health status of children, especially in detecting the occurrence of stunting and improving the achievement of immunization services. Lack of family access to nutritious food is related to the problem of stunting. The family's economic condition is still on less average while the price of nutritious food in Indonesia is still relatively expensive. Many people in the Langkat district of Secanggang subdistrict are categorized as underprivileged/below the minimum wage (minimum wage), making it impossible to meet the nutritional needs of infants and children (Table 4). The existence of a culture of food abstinence in families such as children should not eat fish and eggs, because it is feared that it will cause itching and intestinal worms in children resulting in the child will be deficient in protein and cause chronic malnutrition in children and eventually stunting [45], [46].

Table 2: Socioculture level of respondents

\begin{tabular}{lll}
\hline Socioculture Level & Frequency & Percentage \\
\hline Good & 17 & 12 \\
Moderate & 36 & 26 \\
Less & 83 & 61 \\
Total & 136 & 100 \\
\hline
\end{tabular}

Sanitation, dirty environment, and lack of access to clean water are related to stunting (Table 5). Many people still employ wells as a source of water in the household. Inadequate well water conditions, water looks dirty and brown, and housing conditions are poorly ventilated, and some families keep livestock close to their homes. In fact, there are some family members who still behave in unhealthy life such as becoming active smokers and often close to children 
and babies when smoking so that other family members are exposed to the pollution. Consequently, this condition will affect the growth and development of children with unhealthy environments [44], [45].

Table 3: Children/babies health status

\begin{tabular}{lll}
\hline Health status & Frequency & Percentage \\
\hline Stunting & 30 & 22.1 \\
Not stunting & 106 & 77.9 \\
Total & 136 & 100 \\
\hline
\end{tabular}

This is in line with research which shows that health, growth, and development status of infants/ children will be determined by environmental and sanitary conditions in their families [47]. Education and family knowledge, especially mothers about stunting, could be related to the incidence of stunting. A mother who has good knowledge about nutrition will try to meet the child's nutritional needs to the optimum level. Furthermore, mothers will try to make a variety of foods to meet the nutritional needs of children so that the nutritional needs of elements can be fulfilled.

Table 4: Analysis of relationship between risk factor with stunting $(n=136)$

\begin{tabular}{|c|c|c|c|}
\hline Variable & Stunting & No stunting & $\mathrm{p}$-value \\
\hline \multicolumn{4}{|l|}{ Age of mother } \\
\hline Risk age & $14(26.9)$ & $38(73.1)$ & \multirow[t]{2}{*}{0.388} \\
\hline Productive age & $16(19)$ & $68(81)$ & \\
\hline \multicolumn{4}{|l|}{ Gender of children } \\
\hline Male & $10(17.5)$ & $47(82.5)$ & \multirow[t]{2}{*}{0.388} \\
\hline Female & $20(25.3)$ & 59 (82.5) & \\
\hline \multicolumn{4}{|l|}{ Number of child } \\
\hline$>2$ children & $16(44.4)$ & $20(55.6)$ & \multirow[t]{2}{*}{0.000} \\
\hline$\leq 2$ children & $14(14.1)$ & 85 (85.9) & \\
\hline \multicolumn{4}{|c|}{ Environment sanitation } \\
\hline Good & $6(7.7)$ & $72(92.3)$ & \multirow[t]{2}{*}{0.000} \\
\hline Worst & $24(41.4)$ & $34(58.6)$ & \\
\hline \multicolumn{4}{|c|}{ Father's educational level } \\
\hline Higher education & $15(18.1)$ & $68(81.9)$ & \multirow[t]{2}{*}{0.233} \\
\hline Low education & $15(28.3)$ & $38(71.1)$ & \\
\hline \multicolumn{4}{|c|}{ Mother's educational level } \\
\hline Higher education & $1(2)$ & $50(80)$ & \multirow[t]{2}{*}{0.000} \\
\hline Low education & $29(34.1)$ & $56(65.9)$ & \\
\hline \multicolumn{4}{|c|}{ Income according to minimum wage } \\
\hline Rp. $3,400,000$ & $10(10)$ & $60(60)$ & \multirow[t]{2}{*}{0.000} \\
\hline$<$ Rp. $3,400,000$ & $20(55.6)$ & $16(44.4)$ & \\
\hline
\end{tabular}

Parents, especially mothers as child caregivers, will be influenced by their education and knowledge about health. This is consistent with the theory which states that knowledge can improve emotional control, increase client independence, self-esteem, endurance, and can help clients to adapt to problems or illnesses which, in turn, can improve health status. The program to improve public health status will not operate smoothly in accordance with the objectives if it does not examine the environmental and sociocultural factors of the surrounding community and involve the community in the program. In addition, human behavior is influenced by the environment, both the physical and the sociocultural environment. Relating to behavioral factors that can affect the health status of the community, especially mothers and infants, are inseparable from the culture and habits of the family and the daily environmental condition of the community. This is in line with the opinion that stated the indirect cause of maternal and newborn deaths is due to community conditions such as education, socioeconomic, and culture [15], [34].
Table 5: Risk factors for stunting by logistic regression

\begin{tabular}{llll}
\hline Variable & Odds ratio & $95 \% \mathrm{Cl}$ & $\mathrm{p}$-value \\
\hline Environment sanitation & 65.56 & $8.51-504.93$ & 0.000 \\
Father's educational level & 0.17 & $0.30-0.95$ & 0.044 \\
Mother's educational level & 129.23 & $8.01-208.35$ & 0.000 \\
Income according to minimum wage & 8.84 & $1.70-45.90$ & 0.011 \\
Mother's knowledge about stunting & 0.08 & $0.00-0.82$ & 0.033 \\
\hline
\end{tabular}

\section{Conclusion}

The results of data analysis show that social culture of society in Langkat Regency, North Sumatra, Indonesia, is significantly related to the incidence of stunting in children, especially social culture on environmental sanitation factors, parents educational background, family income, and mother's knowledge of stunting. This finding is expected to give insight into every related party to give more attention toward the stunting issue, to avoid similar problem to happen in the future. As it is discussed, many factors are involved, which means that it is not a simple problem to be solved.

\section{Acknowledgment}

Authors would like to acknowledge Universitas Sumatera Utara Research Institution for providing research funding through "TALENTA" scheme. Furthermore, authors send gratitude to Secanggang Health Center and communities.

\section{Ethical clearance}

In addition, this research has been approved by Ethical Committee of Nursery Faculty, Universitas Sumatera Utara, Indonesia, with ethical clearance number of $1826 /$ IV/SP/2019.

\section{References}

1. Aryanti M. Relationship Between Diet and Health with the Health Status of Children Under Five Years Old. Medan: Universitas Sumatera Utara; 2010.

2. Almatsier H. Prinsip Dasar Ilmu Gizi. Jakarta: Gramedia Pustaka Utama; 2010

3. Buisman LR, Van de Poel E, O'Donnell O, van Doorslaer EK. What explains the fall in child stunting in Sub-Saharan Africa? SSM Popul Health 2019;8:100384. https://doi.org/10.1016/j. ssmph.2019.100384

4. Utami RA, Setiawan A, Fitriyani P. Identifying causal risk factors for stunting in children under five years of age in South Jakarta, Indonesia. Enferm Clín. 2019;29(2):606-11. https://doi. 
org/10.1016/j.enfcli.2019.04.093

PMid:31311736

5. Research Institute IFPRI, IFP. Global Nutrition Report. Gujarat: Research Institute IFPRI, IFP; 2014. https://doi. org/10.2499/9780896295643

6. Indonesian Department of Health. Child Growth Monitoring. Jakarta: Direktorat Gizi Masyarakat, Indonesia; 2010.

7. Indonesian Department of Health. Guidelines to a Balanced Nutrition. Jakarta: Departemen Kesehatan Republik Indonesia; 2012.

8. Voth-Gaeddert LE, Stoker M, Cornell D, Oerther DB. What causes childhood stunting among children of San Vicente, Guatemala: Employing complimentary, system-analysis approaches. Int J Hyg Environ Health. 2018;221(3):391-9. https://doi.org/10.1016/j.ijheh.2018.01.001

PMid:29325698

9. Kordas K, Siegel EH, Olney DK, Katz J, Tielsch JM, Chwaya HM, et al. Maternal reports of sleep in 6-18 month-old infants from Nepal and Zanzibar: Association with iron deficiency anemia and stunting. Early Hum Dev. 2008;84(6):389-98. https://doi. org/10.1016/j.earlhumdev.2007.10.007

PMid:18022771

10. Reurings $M$, Vossenaar $M$, Doak $C M$, Solomons NW. Stunting rates in infants and toddlers born in metropolitan Quetzaltenango, Guatemala. Nutrition. 2013;29(4):655-60. https://doi.org/10.1016/j.nut.2012.12.012 PMid:23466051

11. Bharti R, Dhillon P, Narzary PK. A spatial analysis of childhood stunting and its contextual correlates in India. Clin Epidemiol Glob Health. 2019;7(3):488-95. https://doi.org/10.1016/j. cegh.2019.04.005

12. Schrijner S, Smits J. Grandparents and children's stunting in Sub-Saharan Africa. Soc Sci Med. 2018;205:90-8. https://doi. org/10.1016/j.socscimed.2018.03.037 PMid:29677583

13. Olds SB, London ML, Ladewig PA. Maternal Newborn Nursing: A Family and Community-based Approach. $6^{\text {th }}$ ed. New Jersey: Prentice Hall Health; 2000.

14. Himaz R. Stunting later in childhood and outcomes as a young adult: Evidence from India. World Dev. 2018;104:344-57. https:// doi.org/10.1016/j.worlddev.2017.12.019

15. Wray J. Bouncing back? An ethnographic study exploring the context of care and recovery after birth through the experiences and voices of mothers. Br J Midwif. 2011;14:320-6.

16. World Health Organization. Global Strategy on Infant and Young Child Feeding. Switzerland: World Health Organization; 2013.

17. Indonesian Ministry of Health. Anthropometric Standards for Assessment of Nutritional Status. Jakarta: KEMENKES RI; 2010.

18. Indonesian Ministry of Health. Situation and Nutritional Analysis. Jakarta: KEMENKES RI; 2015.

19. Nasution S, Badaruddin B, Dasatjipta G, Lubis Z. Effectiveness of the health awareness community team intervention in improving the maternal and neonatal health status in Mandailing Natal (Madina) district, Sumatera Utara, Indonesia. Int J Med Sci Public Health. 2015;4:799. https://doi.org/10.5455/ ijmsph.2015.26022015163

20. Setyowati S, Rosnani R. Women's efforts to solve postpartum problems based on the culture of South Sumatera. Enferm Clín. 2019;29(2):653-8. https://doi.org/10.1016/j.enfcli.2019.04.100 PMid:31302026

21. Marx D. Patient safety and the just culture. Obstet Gynecol Clin North Am. 2019;46:239-45. https://doi.org/10.1016/J. OGC.2019.01.003

PMid:31056126
22. Badriah S, Sahar J, Gunawijaya J, Prasetyo S. Pampering older people with diabetes in Sundanese culture: A qualitative study. Enferm Clín. 2019;29(2):733-8. https://doi.org/10.1016/j. enfcli.2019.04.111

PMid:31331732

23. Green LW, Kreuter MW. Health Program Planning: An Educational and Ecological Approach. New York: McGraw-Hill; 2005.

24. Mikkelsen B. Metode Penelitian Parsipatoris dan Upaya Pemberdayaan (Participatory Research Methods and Empowerment Efforts). Jakarta: Yayasan Pustaka Obor Indonesia; 2011.

25. McKenzie JF, Pinger RR, Kotecki JE. An Introduction to Community Health. $7^{\text {th }}$ ed. Sudburry: Jones and Barlett Learning; 2011.

26. Giger JN. Transcultural Nursing : Assessment and Intervention. Missouri: C.V. Mosby Co.; 1995.

27. May KA, Mahlmeister LR. Maternal and Neonatal Nursing Family Centred Care. $4^{\text {th }}$ ed. Philadelpia, PA: J.B. Lippincott Company; 1994.

28. Syafrudin S, Mariam N. Basic Socio-cultural Book for Midwifery Students. Jakarta: Trans Info Media; 2010.

29. Sulistijani DA, Herlianty MP. Maintaining the Health of Babies and Toddlers. Jakarta: Puspa Swara; 2011.

30. Twinn $S$. The evaluation of the effectiveness of health education interventions in clinical practice: A continuing methodological challenge. J Adv Nurs. 2001;34(2):230-7. https://doi. org/10.1046/j.1365-2648.2001.01749.x

PMid: 11430285

31. Yudi H. The Relationship between Socio-cultural Factors and Nutritional Status of Children Aged 6-24 Months in Medan Area District, Medan City. Indonesia: Universitas Sumatera Utara; 2008.

32. Nasution SS, Erniyati E, Aizar E. The effectiveness of DC motor vibrilatory stimulus (DMV) among postpartum women on giving breast milk. Open Access Maced J Med Sci. 2018;6(12):2306-9. https://doi.org/10.3889/oamjms.2018.436 PMid:30607181

33. Matteson PS. Woman's Health During the Childbearing Years : A Community Based Approach. St. Louis: Mosby Inc.; 2001.

34. Blakstad MM, Smith ER, Etheredge A, Locks LM, McDonald $\mathrm{CM}$, Kupka R, et al. Nutritional, socioeconomic, and delivery characteristics are associated with neurodevelopment in tanzanian children. J Pediatr. 2019;207:71-9.e8. https://doi. org/10.1016/j.jpeds.2018.10.066 PMid:30559023

35. Helton JJ, Moore AR, Henrichsen C. Food security status of mothers at-risk for child maltreatment. Child Youth Serv Rev. 2018;93:263-9. https://doi.org/10.1016/j.childyouth.2018.07.031

36. Cui Y, Liu H, Zhao L. Mother's education and child development: Evidence from the compulsory school reform in China. J Comp Econ. 2019;47:669-92. https://doi.org/10.1016/j. jce.2019.04.001

37. Wei S, Lv Y, Fu B, Yoshino H. The correlation study on the living environment and children's health problem in Dalian. Proc Eng. 2016;146:158-65. https://doi.org/10.1016/j.proeng.2016.06.367

38. Sun Y, Sundell J. Life style and home environment are associated with racial disparities of asthma and allergy in Northeast Texas children. Sci Total Environ. 2011;409(20):4229-34. https://doi. org/10.1016/j.scitotenv.2011.07.011

PMid:21802705

39. Fitrinitia IS, Suyanti E, Junadi P, Gustada H. Integration of spatial characteristic to health services for improvement of children health. Int J GEOMATE. 2019;17(61):163-8. https://doi. org/10.21660/2019.61.8267 
40. Yusdarif Y. Determinants of Stunting Incidence in Toddlers Aged 24-59 Months in Rangas Village, Banggae District, Majene Regency, 2017. Indonesia: Universitas Islam Negeri Alaudidin Makassar; 2017.

41. Wong DL. Pediatric Nursing Textbook. Jakarta: EGC; 2008.

42. Sarafino EP. Health Psychology: Biopsychology Interactions. New York: John Wiley and Sons, Inc.; 1990.

43. Soetjiningsih S. Child Development. Jakarta: EGC; 1995.

44. Susanto T, Rahmawati I, Wuryaningsih EW, Saito R, Syahrul, Kimura $\mathrm{R}$, et al. Prevalence of factors related to active reproductive health behavior: A cross-sectional study Indonesian adolescent. Epidemiol Health. 2016;38:e2016041. https://doi. org/10.4178/epih.e2016041

PMid:27866406

45. Cheng HG, Chen S, McBride O, Phillips MR. Prospective relationship of depressive symptoms, drinking, and tobacco smoking among middle-aged and elderly community-dwelling adults: Results from the China health and retirement longitudinal study (CHARLS). J Affect Disord. 2016;195:136-43. https://doi. org/10.1016/j.jad.2016.02.023

PMid:26895091

46. Mardiana M. Relationship between Maternal Nutritional Behavior and Nutritional Status of Toddlers in Tanjung Beringin Public Health Center, Hinai Sub-district, Langkat Regency. Indonesia: Universitas Sumatera Utara; 2006.

47. Sartono A, Utaminingrum $\mathrm{H}$. Relationship between mother's knowledge, mother's education and husband's support with the practice of giving exclusive breastfeeding in Muktiharjo Kidul village, Telogosari district, Semarang city. J Gizi Univ Muhammadiyah Semarang. 2012;1:1-9. 